\title{
Board of Director Independence and Financial Leverage in the Absence of Taxes
}

\author{
Omar Almania ${ }^{1}$ \\ ${ }^{1}$ Al Imam Muhammad Ibn Saud Islamic University, Riyadh, Saudi Arabia \\ Correspondence: Omar Almania, Al Imam Muhammad Ibn Saud Islamic University, Riyadh, Saudi Arabia. \\ E-mail: omaralmanea@gmail.com
}

Received: February 23, 2017

Accepted: March 5, 2017

Online Published: March 15, 2017

doi:10.5539/ijef.v9n4p90

URL: https://doi.org/10.5539/ijef.v9n4p90

\begin{abstract}
This paper investigates whether board of director independence affects the financial leverage of listed companies in Saudi Arabia. Although many studies have investigated capital structure theories, there are limited studies that consider board of director independence as a determinant of capital structure especially in the absence of tax regime. In a tax free regime, financial leverage would not be perceived as a tool to increases firm performance since firms cannot exploit the tax shield. This study employs panel data of 122 non-financial listed firms during the period 2012-2015. The results show a significant negative relationship between the presence of independent directors and capital structure; the independent directors appeared to play a significant role in motivating managers to pursue a low level of leverage among Saudi listed firms. This finding is robust to different model specifications.
\end{abstract}

Keywords: financial policies, capital structure, board of director independence, corporate governance, financial leverage

\section{Introduction}

Capital structure refers to the mix of debt and equity employed for the purpose of financing the operations of a company. It is crucial for firms to decide whether they finance their operations by debt or equity (Glen \& Pinto, 1994). Furthermore, Capital structure has been one of the most important issues in the field of finance literature over the last decades. Similarly, corporate governance is a growing field of research that has become more attractive in recent years. Corporate governance commonly means the list of mechanisms that affect the managers`decisions when there is independence between ownership and control. According to Cadbury (1992), a governance system has been defined by the Cadbury Committee as "the system by which companies are directed and controlled." The component of capital structure is a demanding decision that is always discussed by the board of directors. According to the Saudi Corporate Governance Code (2006), discussing the capital structure of a firm is considered to be a main function of the board of directors.

Although many studies have investigated capital structure theories, as well as the determinants of the financing decision, there are limited studies that consider board of directors independence as a determinant of capital structure. Additionally, most of the research into corporate governance concentrates on the effects of corporate governance practices on a firm's value, while limited papers investigate their impacts on the financing decision. In addition, the existing literature on corporate governance concentrates more on developed countries (Baydoun et al., 2012) while there is less attention paid to developing countries. Additionally, it is worthwhile to investigate this issue in the absence of tax regime. Financial leverage is perceived as a tool to increases firm performance because of the tax shield. However, in the absence of taxes, firms cannot benefit from the tax shield. Therefore, this research aims to contribute to previous works by looking at an emerging country which is Saudi Arabia where there is no taxes. Consequently, the proposed study intends to add to the existing body of literature by finding whether the board of director independence have an effect on the financing decisions of listed companies in Saudi Arabia during the period 2012-2015.

Jensen (1986), Berger et al. (1997), and Abor and Biekpe (2007) argue that there is a positive correlation between the proportion of independent directors and debt ratio. The developers of the 'resource dependence Approach', Pfeffer (1973) and Pfeffer and Salancick (1978), highlight upon the fact that firms which have outside directors are more competent, and are better able to handle the uncertainties that may occur in the 
external environment. Other than that, it is the external directors that allow the firm to adapt to the external environment in a more efficient way, and protect the firm from its insecurities. Moreover, they have the ability to make use of all those resources which may enhance the performance of the firm and allow them to raise finances. Conversely, executive directors might prefer to minimize the stress of the performance on them that associated with high financial leverage by adopting low level of debt. Consequently, there is a conflict between executive and non-executive directors regarding the level of debt (agency cost). Executive directors prefer to have low level of debt in contrast with external directors who prefer high leverage to enhance the performance of the firm.

On the other hand, Wen et al. (2002) and Kuo et al. (2012) find that when the number of external directors increases, the firm tends to have a lower level of debt which means there is a negative correlation between the presence of external directors on the board and debt. That has been interpreted as managers tend to be monitored by independent directors, which encourages the managers to pursue a low level of debt to achieve better performance throughout minimizing firm riskiness (Wen et al., 2002). Additionally, and in the absence of tax regime, financial leverage would not be perceived as a tool to increases firm performance since firms cannot exploit the tax shield. Therefore, this study expects that the relationship between the presence of external directors and leverage is negative.

H1: A negative relationship will exist between the presence of independent directors and leverage.

\section{Method}

The sample used in this study is 122 listed firms in the Saudi Stock Market. The data is collected manually from the annual reports of the companies published on the Saudi Stock Exchange's official website (www.tadawul.com.sa).

To test the relationship between corporate governance mechanisms and the debt to equity ratio, the study intends to run an OLS regression by employing panel data which contains both cross-sectional and time series data.

The study aims to use the model that has been used by Abor (2007) and Wen et al. (2002) with some modifications. The research model is:

$$
L V=\alpha_{0}+\beta_{1} I D_{i, t}+\sum_{i=1}^{n} \beta_{i} \operatorname{CONTROLS}_{i t}+\varepsilon_{i t}
$$

Where:

$\mathrm{LVi}, \mathrm{t}=$ total debt/(total assets) for firm $\mathrm{i}$ in time $\mathrm{t}$;

$\mathrm{IDi}, \mathrm{t}=$ number of outside directors/total number of directors for firm $\mathrm{i}$ in time $\mathrm{t}$;

Controls:

SIZEi, $\mathrm{t}=$ size of the firm (log of total assets) for $\mathrm{i}$ in time $\mathrm{t}$;

$\mathrm{ROEi}, \mathrm{t}=$ return on total equity for firm $\mathrm{i}$ in time $\mathrm{t}$;

RISK $=$ beta for firm $\mathrm{i}$ in time $\mathrm{t}$;

GROWi, $\mathrm{t}=\mathrm{PB}$ ratio for firm $\mathrm{i}$ in time $\mathrm{t}$;

LIQ = current $/$ current liabilities for firm $\mathrm{i}$ in time $\mathrm{t}$; and

$\varepsilon=$ the error term.

\section{Results}

Descriptive statistics for the quantitative variables involved in the study are shown in table 1 in the following.

Table 1. Descriptive statistics

\begin{tabular}{|c|c|c|c|c|c|}
\hline \multicolumn{6}{|c|}{ Descriptive Statistics } \\
\hline & $\mathrm{N}$ & Minimum & Maximum & Mean & Std. Deviation \\
\hline leverage & 463.00 & 0.00 & 2.98 & 0.23 & 0.23 \\
\hline ROE & 463.00 & -9.80 & 2.50 & 0.08 & 0.58 \\
\hline $\log \mathrm{TA}$ & 463.00 & 1.72 & 5.93 & 3.40 & 0.71 \\
\hline WC ratio & 463.00 & 0.06 & 19.96 & 2.53 & 2.61 \\
\hline beta & 463.00 & 0.07 & 2.52 & 1.09 & 0.41 \\
\hline ID & 463.00 & 0.00 & 1.00 & 0.49 & 0.17 \\
\hline Valid N (listwise) & 463.00 & & & & \\
\hline
\end{tabular}


Leverage has mean of 0.23 which is relatively a low level of debt. This is consistent with the result of (Aldohaiman, 2008) where he finds that, on average, Saudi listed firms have leverage of $10.9 \%$ while it is $16.3 \%$ in unlisted ones. To compare this low level of leverage with the international context we referred to the results of the work done by Rajan and Zingales (1995). They found the mean of leverage for Japan, Italy, Germany, United Kingdom, France, United States and Canada are 0.52, 0.46, 0.39, 0.29, 0.46, 0.37, and 0.39 respectively. Moreover, Abor (2007) finds that on average Ghanaian firms are financed by $58 \%$ debt. This shows that, on average, listed Saudi firms are under levered.

The mean of the presence of external directors of Saudi listed firms is $49 \%$. This result is slightly similar to result in the US obtained by Harford et al, (2012) where the presence of independent directors is $64 \%$.

Correlation matrix is found to assess relationship of predictors with leverage as well as of predictors among themselves. Table 2 shows the correlation matrix.

Table 2. The correlation matrix

\begin{tabular}{lccccccc}
\hline & leverage & PB & ROE & LogTA & WC ratio & beta & ID \\
\hline leverage & 1 & -.229 & 0.059 & .347 & -.372 & 0 & -.208 \\
PB & -.229 & 1 & .204 & -.241 & $-.005-$ & -.216 & 0.028 \\
ROE & 0.059 & .204 & 1 & .112 & 0.037 & -.170 & -.046 \\
LogTA & .347 & -.241 & .112 & 1 & -.178 & -.109 & -.376 \\
WC ratio & $-.372-$ & -.005 & 0.037 & -.178 & 1 & .115 & 0.036 \\
beta & 0 & -.216 & -.170 & -.109 & .115 & 1 & 0.065 \\
ID & $-.208-$ & 0.028 & -.046 & -.376 & 0.036 & 0.07 & 1 \\
\hline
\end{tabular}

However, the casual relationship between variables cannot be identified by correlation analysis which motivates this study to employ a regression model. The regression model is shown in table 3.

Table 3. Regression analysis

\begin{tabular}{|c|c|c|c|}
\hline \multicolumn{4}{|l|}{ Dependent variable: LV } \\
\hline Variable & Coefficient & Std. Error & t-statistics \\
\hline ID & $-.113^{* *}$ & .056 & -2.005 \\
\hline $\mathrm{PB}$ & $-.015^{* * *}$ & .004 & -3.769 \\
\hline $\log \mathrm{TA}$ & $.092 * * *$ & .018 & 5.201 \\
\hline WC ratio & $-.028 * * *$ & .003 & -8.003 \\
\hline beta & .013 & .024 & .536 \\
\hline petrochemical & -.005 & .051 & -.105 \\
\hline retails & $-.214 * * *$ & .075 & -2.863 \\
\hline Power & $-.505 * * *$ & .110 & -4.582 \\
\hline Agriculture & $-.366 * * *$ & .108 & -3.388 \\
\hline Telecomunication & $-.569 * * *$ & .138 & -4.125 \\
\hline Multiinvestment & $-.564 * * *$ & .145 & -3.892 \\
\hline Industrial & $-.538 * * *$ & .167 & -3.226 \\
\hline Building & $-.566 * * *$ & .202 & -2.798 \\
\hline Real state & $-.899 * * *$ & .231 & -3.889 \\
\hline Transportation & $-.896^{* * *}$ & .245 & -3.653 \\
\hline Media & $-.797 * * *$ & .256 & -3.115 \\
\hline Hotels \&amp; Tourism & $-1.03 * * *$ & .261 & -3.952 \\
\hline 2015 & $.045^{*}$ & .024 & 1.851 \\
\hline 2014 & .032 & .025 & 1.299 \\
\hline 2013 & .004 & .024 & .144 \\
\hline ROE & .019 & .016 & 1.208 \\
\hline (Constant) & -.075 & .094 & -.806 \\
\hline Adjusted R Square & .397 & Sample: 2 & \\
\hline F-statistics & 14.840 & Cross-sect & \\
\hline Prob(F-statistics) & 0.000000 & Total pane & \\
\hline
\end{tabular}


The study assumes a negative relationship between the proportion of independent directors and leverage. The regression results indicate that there is a significant negative association between the presence of outside directors and capital structure in the Saudi listed firms. This relationship is significant at 0.05 level. This finding supports the hypothesis that the greater the number of external directors of a firm, the lower the level of leverage of the firm as proposed in the literature review section. Therefore, the current study rejects the null hypothesis. This finding is in line with the findings by Wen et al. (2002) and Kuo et al. (2012). The explanation of the negative association is that executives tend to be monitored by independent directors, which motivate the managers to pursue a low level of leverage in order to achieve better performance (Wen et al., 2002).

Among control variables, Size, liquidity and growth opportunity are significant at 0.01 level of significance. Firm size is positively related with leverage while liquidity and growth opportunity are negatively associated with leverage.

\section{Robustness Check}

For robustness check, this study uses two models to increase the reliability of findings: (i) a random effect model, (ii) the employment of another measure of financial leverage. Total liabilities/total assets ratio is used as another proxy of leverage. Table 4 illustrates the findings of the two new models. The results of two models show that board of directors independence is negatively and significantly - at 0.01 level - related to financial leverage. Thus, the findings of this study are robust to different model specifications.

Table 4. Robustness check

\begin{tabular}{|c|c|c|c|c|c|c|}
\hline \multirow[b]{2}{*}{ Variable } & \multicolumn{2}{|c|}{ OLS: LV } & \multicolumn{2}{|c|}{ Random effect: LV } & \multicolumn{2}{|c|}{ OLS: LV2* } \\
\hline & Coefficient & t-statistics & Coefficient & t-statistics & Coefficient & t-statistics \\
\hline ID & $-.113^{* *}$ & -2.005 & $-0.137 * * *$ & -2.373 & $-0.049 * * *$ & -2.827 \\
\hline PB & $-.015 * * *$ & -3.769 & 0.059 & -0.712 & $-0.008 * *$ & -2.336 \\
\hline $\log \mathrm{TA}$ & $.092 * * *$ & 5.201 & $-0.005^{* * *}$ & 2.648 & $0.345^{* * *}$ & 15.668 \\
\hline ROE & 0.019 & 1.208 & 0.006 & -0.492 & $-0.298 * *$ & -2.371 \\
\hline WC ratio & $-.028 * * *$ & -8.003 & $-0.013^{* * *}$ & -3.994 & $-0.073^{* * *}$ & -18.379 \\
\hline beta & 0.013 & 0.536 & -0.003 & 0.930 & $0.249^{* * *}$ & 5.261 \\
\hline petrochemical & -0.005 & -0.105 & $0.017^{* *}$ & 2.503 & $0.263 * * *$ & 3.494 \\
\hline retails & $-.214 * * *$ & -2.863 & 0.013 & 0.211 & $0.182 * * *$ & 16.415 \\
\hline Power & $-.505 * * *$ & -4.582 & -0.113 & -0.928 & 0.036 & 1.086 \\
\hline Agriculture & $-.366^{* * *}$ & -3.388 & 0.003 & 0.045 & $0.116 * * *$ & 8.800 \\
\hline Telecomunication & $-.569 * * *$ & -4.125 & -0.027 & -0.294 & $-0.207 * * *$ & -3.859 \\
\hline Multiinvestment & $-.564 * * *$ & -3.892 & -0.026 & -0.341 & 0.095 & 1.315 \\
\hline Industrial & $-.538 * * *$ & -3.226 & $0.101 *$ & 1.680 & $0.409 * * *$ & 5.093 \\
\hline Building & $-.566 * * *$ & -2.798 & $0.215 * * *$ & 3.608 & $0.497 * * *$ & 7.107 \\
\hline Real state & $-.899 * * *$ & -3.889 & -0.010 & -0.142 & $-0.183 * * *$ & -9.194 \\
\hline Transportation & $-.896 * * *$ & -3.653 & 0.035 & 0.414 & $0.111^{* * *}$ & 2.689 \\
\hline Media & $-.797 * * *$ & -3.115 & 0.153 & 1.498 & $0.534 * * *$ & 9.303 \\
\hline Hotels \&amp; Tourism & $-1.03 * * *$ & -3.952 & -0.041 & -0.445 & $-0.138 * * *$ & -5.465 \\
\hline 2015.000 & $.045^{*}$ & 1.851 & $0.048^{* * *}$ & 3.274 & $0.068^{* * *}$ & 3.562 \\
\hline 2014.000 & 0.032 & 1.299 & $0.027 *$ & 1.750 & $0.089 * * *$ & 10.028 \\
\hline 2013.000 & 0.004 & 0.144 & 0.006 & 0.416 & $0.014 * * *$ & 6.250 \\
\hline (Constant) & -0.075 & -0.806 & 0.036 & 0.345 & $-0.887 * * *$ & -6.503 \\
\hline Adjusted R Square & \multicolumn{2}{|c|}{.397} & \multicolumn{2}{|c|}{0.130} & \multicolumn{2}{|c|}{0.574} \\
\hline F-statistics & \multicolumn{2}{|c|}{14.840} & \multicolumn{2}{|c|}{4.308} & \multicolumn{2}{|c|}{30.687} \\
\hline Prob(F-statistics) & \multicolumn{2}{|c|}{0.000000} & \multicolumn{2}{|c|}{0.000000} & \multicolumn{2}{|c|}{0.000000} \\
\hline Cross-sections included & \multicolumn{2}{|c|}{122} & \multicolumn{2}{|c|}{122} & \multicolumn{2}{|c|}{122} \\
\hline Total panel observation & \multicolumn{2}{|c|}{463} & \multicolumn{2}{|c|}{463} & \multicolumn{2}{|c|}{463} \\
\hline
\end{tabular}

* LV2 is another proxy to measure the financial leverage through the equation: total liabilities/total assets.

\section{Conclusion}

The present study tries to investigate the effect of board of director independence on capital structure in the Saudi context. This work is motivated by the fact that limited studies consider the board of director independence as a 
determinant of financial leverage in spite of the massive research efforts that investigate capital structure theories. Additionally, this study is encouraged by the reality that the existing literature on corporate governance concentrates more on developed countries (Baydoun et al., 2012) while there is less attention paid to developing countries. Saudi Arabia is categorized as an emerging market.

The study hypothesized that the proportion of external directors is negatively associated with level of debt. To test the hypotheses, the present research runs a regression by employing panel data which contains both cross-sectional and time series data of 122 listed non-financial firms during the period 2012-2015 with total of 463 observations. The findings show that there is a significant negative relationship between the presence of independent directors and capital structure in the Saudi listed firms. The findings are robust to different model specifications.

\section{References}

Abor, J. (2007). Corporate governance and financing decisions of Ghanaian listed firms. Corporate Governance: The International Journal of Business in Society, 7(1), 83-92. http://dx.doi.org/10.1108/14720700710727131

Abor, J., \& Biekpe, N. (2007). Corporate governance, ownership structure and performance of SMEs in Ghana: implications for financing opportunities. Corporate Governance: The International Journal of Business in Society, 7(3), 288-300. http://dx.doi.org/10.1108/14720700710756562

Ahmadpour, A., Samimi, A. J., \& Golmohammadi, H. (2012). Corporate Governance and Capital Structure: Evidence from Tehran Stock Exchange. Middle-East Journal of Scientific Research, 11(4), 531-535.

Aldohaiman, M. (2008). Capital structure in Saudi Arabian listed and unlisted companies.

Baydoun, N., Maguire, W., Ryan, N., \& Willett, R. (2012). Corporate governance in five Arabian Gulf countries. Managerial Auditing Journal, 28(1), 7-22.

Berger, P. G., Ofek, E., \& Yermack, D. L. (1997). Managerial entrenchment and capital structure decisions. The Journal of Finance, 52(4), 1411-1438.

Cadbury Committee. (1992). Report of the Committee on the Financial Aspects of Corporate Governance: The Code of Best Practice. London, UK: Gee Professional Publishing.

Glen, J. D., \& Pinto, B. (1994). Debt or equity? How firms in developing countries choose (Vol. 63). World Bank Publications.

Harford, J., Mansi, S. A., \& Maxwell, W. F. (2012). Corporate governance and firm cash holdings in the US. Corporate Governance, 107-138.

Jensen, M. C. (1986). Agency cost of free cash flow, corporate finance, and takeovers. Corporate Finance, and Takeovers. American Economic Review, 76(2).

Kuo, H. C., Wang, L. H. \& Liu, H. W. (2012). Corporate Governance and Capital Structure: Evidence from Taiwan SMEs. Review of Economics \& Finance, 2, 43-58.

Pfeffer, J. (1973). Size, composition, and function of hospital boards of directors: A study of organization-environment linkage. Administrative Science Quarterly, 349-364.

Pfeffer, J., \& Salancick, G.R. (1978). The External Control of Organisations: A Resource-dependence Perspective. New York, NY: Harper \& Row.

Rajan, R. G., \& Zingales, L. (1995). What do we know about capital structure? Some evidence from international data. The journal of Finance, 50(5), 1421-1460.

Wen, Y., Rwegasira, K., \& Bilderbeek, J. (2002). Corporate governance and capital structure decisions of the Chinese listed firms. Corporate Governance: An International Review, 10(2), 75-83. http://dx.doi.org/10.1111/1467-8683.00271

\section{Copyrights}

Copyright for this article is retained by the author(s), with first publication rights granted to the journal.

This is an open-access article distributed under the terms and conditions of the Creative Commons Attribution license (http://creativecommons.org/licenses/by/4.0/). 